that play nicely with their new neighbours. For every pest, there are many more unobtrusive immigrants that live quietly in their new haunts, even helping the growth and development of native species. This does not mean that invading species are never a problem, but Davis argues that they are not always troublesome.

Davis writes well, and clearly. But his big contribution is to the sceptical re-examination of the field as a whole. This book will not kill it off. But if, over time, invasion biology were to become absorbed into broader ecological fields that focus on the movement of species, future historians of science might see Invasion Biology as the beginning of the end.

Emma Marris writes for Nature from Missouri.

\title{
Paper ambassadors of science
}

\section{Philip Parker of Britain's Royal Mail celebrates special stamps and his new set for the 250th anniversary of the Royal Botanic Gardens at Kew.}

After Queen Elizabeth II, the most featured individual on British postage stamps is a scientist. Charles Darwin has appeared on four stamp issues, in 16 different stamp designs, in the past 30 years. The last set, issued on 12 February this year to commemorate the bicentenary of his birth, used a jigsaw design to illustrate the interconnectedness of the varied disciplines zoology, botany, geology - that Darwin synthesized into his theory of evolution. A separate sheet of four stamps makes up the hydrographic map of the Galapagos Islands that resulted from the voyage of HMS Beagle.

Darwin's popularity as a subject for stamps is appropriate because he was a prodigious letter writer. From its introduction in 1840, the Penny Post was the Internet of its day, facilitating peer review among scientists. With the service came the postage stamp, which is arguably the most widespread and visible platform for public art.

For 50 years, alongside the everyday stamps showing the Queen, Royal Mail has been issuing pictorial stamps to mark aspects of British heritage and contemporary life. They are produced in hundreds of millions, and competition for topics is fierce. Every year Royal Mail receives around 2,000 requests for subjects. These are filtered using certain criteria - anniversaries are covered in 50-year multiples, and themes must be of national importance or celebrate the national character. Intensive desk research and public consultation funnels these down to a continuing programme of around 13 or 14 stamp issues per year.

Subjects are chosen for a range of audiences, from postal historians to the average letter sender. Themes include both light and shade; for example, an impressive set on the grandest cathedrals can be followed by stamps celebrating the fiftieth birthday of the Carry On comedy films - and both can be equally successful.

Postal offices worldwide issue pictorial stamps, and science is frequently celebrated. Scientific concepts are often difficult to illustrate concisely, so scientists are more often depicted. The handsome 2008 stamps from the United States feature portraits of chemist

Published on 19 May, the Royal Mail's latest stamp issue marks the 250th anniversary of the founding of the Royal Botanic Gardens at Kew, near London. A set of four stamps feature images of key landmarks at both Kew and Wakehurst Place in West Sussex, where the Millennium Seed Bank aims to conserve $10 \%$ of the world's seed-bearing flora by 2010 . Alongside are ten stamps of UK endangered plants, many of which Kew is actively conserving. Delicate botanical art is used to portray these species, six examples of which are drawn from Kew's extensive art collection.

Royal Mail works closely with partner organizations, such as Kew, and other experts in the field being portrayed, to cross-check every fact and ensure the content is accurate. In-house specialists commission and manage the work of external designers and illustrators, who may work on the same subject but to different briefs. One specialist might consider photography, another might create new illustrations, and a third could explore existing botanical art. The preferred approach is picked after consultation and discussion with the independent Stamp Advisory Committee. For the ten plant stamps, the style of botanical art was found to give the clearest, most accurate and most engaging depictions in such a small space. Once the final designs are proofed to satisfaction, they are submitted for approval by the Queen before printing.

The Plants sequence is the latest in the Action for Species series. Every year, ten stamps are issued depicting threatened UK species, for which there are conservation plans in place. The series began with Birds in 2007, continued with Insects in 2008, and a set on mammals is being prepared for next year. The series has been devised as a countdown to the International Year of Biodiversity in 2010. Another major set of forthcoming stamps will mark the Royal Society's 350th anniversary in 2010.

Stamps are 'paper ambassadors'. Affixed to letters and parcels, they can end up in any corner of the world, Stamps are arguably the most visible form of public art.

Linus Pauling and astronomer Edwin Hubble, among others.

Indeed, one of the most popular stampcollecting themes globally is astronomy. But flora and fauna are consistently attractive to the public, and science and engineering topics generally do well. Royal Mail's earliest special stamps highlighted the opening of the Forth Road Bridge in 1964, and Jodrell Bank's radio telescope in 1966. However, success is all in the detail and in the translation of the subject on to the tiny canvas of a stamp. where the receiver will form an opinion of the sender, of the country of origin, that country's sense of self and its global contribution. This is why Royal Mail pays so much attention to detail on its stamps - they illustrate, in the best sense, the best of British.

Philip Parker is head of stamp policy at Royal Mail, 35 Rathbone Place, London W1T 1HQ, UK. e-mail:philip.parker@royalmail.com

For details of Royal Mail's Plants stamps, see online at www.royalmail.com/plants. 